\title{
Review of the literature and suggestions for the design of rodent survival studies for the identification of compounds that increase health and life span
}

\author{
Stephen Richard Spindler
}

Received: 2 September 2010 / Accepted: 21 February 2011 /Published online: 22 March 2011

(C) The Author(s) 2011. This article is published with open access at Springerlink.com

\begin{abstract}
Much of the literature describing the search for agents that increase the life span of rodents was found to suffer from confounds. One-hundred-six studies, absent 20 contradictory melatonin studies, of compounds or combinations of compounds were reviewed. Only six studies reported both life span extension and food consumption data, thereby excluding the potential effects of caloric restriction. Six other studies reported life span extension without a change in body weight. However, weight can be an unreliable surrogate measure of caloric consumption. Twenty studies reported that food consumption or weight was unchanged, but it was unclear whether these data were anecdotal or systematic. Twenty-nine reported extended life span likely due to induced caloric restriction. Thirty-six studies reported no effect on life span, and three a decrease. The remaining studies suffer from more serious confounds. Though still widely cited, studies showing life span extension using shortlived or "enfeebled" rodents have not been shown to predict longevity effects in long-lived animals. We suggest improvements in experimental design that will enhance the reliability of the rodent life span literature.
\end{abstract}

Electronic supplementary material The online version of this article (doi:10.1007/s11357-011-9224-6) contains

supplementary material, which is available to authorized users.

S. R. Spindler $(\bowtie)$

Department of Biochemistry, University of California,

Riverside, CA 92521, USA

e-mail: spindler@ucr.edu
First, animals should receive measured quantities of food and its consumption monitored, preferably daily, and reported. Weights should be measured regularly and reported. Second, a genetically heterogeneous, longlived rodent should be utilized. Third, chemically defined diets should be used. Fourth, a positive control (e.g., a calorically restricted group) is highly desirable. Fifth, drug dosages should be chosen based on surrogate endpoints or accepted cross-species scaling factors. These procedures should improve the reliability of the scientific literature and accelerate the identification of longevity and health span-enhancing agents.

Keywords Longevity therapeutics - CR mimetics · Geroprotectors · Health span · Life span · Longevity · Drug discovery $\cdot$ Pharmaceutical testing

\section{Introduction}

There are presently no authentic longevity therapeutics. Such compounds would intervene in the process of aging to extend mean and/or maximum life span, maintain physiological function, and mitigate the onset and severity of a broad spectrum of agerelated diseases in mammals. Such drugs might engage the pathways used by caloric, methionine, and phenylalanine restriction, and the longevityenhancing mutations (reviewed in Spindler 2009). The terms "CR mimetics" and "geroprotectors" have been used to describe such compounds (Weindruch et 
al. 2001; Roth et al. 2001; Cao et al. 2001; Anisimov 1982; Lippman 1981). In this report, we will use the general term "longevity therapeutics."

While a full understanding of the mechanisms of aging will greatly facilitate the development and deployment of longevity therapeutics, drug discovery and development have a long history of using surrogate assays for identifying therapeutics, often with little knowledge or understanding of the etiology of the diseases for which the therapeutics were intended (discussed in Spindler 2006). Indeed, most of the medications currently in our armamentarium were discovered using surrogate assays. Thus, the development and refinement of surrogate assays for longevity therapeutics should speed their identification.

There have been multiple methods used in the attempt to identify such compounds. For example, we and others have utilized genome-wide microarray studies of treated mice to identify potential therapeutics (Barger et al. 2008; Spindler and Dhahbi 2007; Spindler and Mote 2007; Spindler 2006; Dhahbi et al. 2005; Corton et al. 2004). Another approach, which will be discussed here, is the direct assays of compounds for their effects on the life span of rodents.

\section{Longevity assays using genetically normal, healthy rodents}

In mice, a number of natural mutations, gene knockouts, and overexpressed transgenes are known to extend longevity and increase health span (Selman et al. 2008; Taguchi et al. 2007; Kurosu et al. 2005; Holzenberger et al. 2003; Flurkey et al. 2001; Coschigano et al. 2000; Zhou et al. 1997; BrownBorg et al. 1996). Thus, potential therapeutic targets for life span extension exist in mammals. However, no robustly effective, safe, and widely recognized longevity therapeutics exist at present. The likely reason that such drugs have not been identified is that we have not mounted an effective search for them. Life span studies in rodents have been used in this search (Table 1 and Electronic supplementary material (ESM) Table 1). More recently, this literature benefits from the improved levels of hygiene used in animal husbandry (e.g., see Sebesteny 1991). For example, several older studies in Table 1 appear to report data consistent with the presence of infectious agents in the rodent colony (Ferder et al. 1993; LaBella and Vivian 1978; Sperling et al. 1978). Despite these improvements, the design and implementation of rodent life span studies could be improved further.

Table 1 and ESM Table 1 summarize and evaluate all of the rodent life span studies we found using repeated key word searches of the online databases. In ESM Table 1, under the heading "Evaluation," we present our evaluation of the study results. ESM Table 1 presents 106 life span studies performed with healthy rodents. We excluded from this table 20 rodent life span studies performed with melatonin, which are contradictory in their results and which have been reviewed elsewhere (Anisimov et al. 2006).

Despite the fact that the effects of caloric restriction on life span were described 76 years ago (McCay et al. 1935), drug screening studies which regulate or measure food consumption are rare. We found only six studies which measured food consumption and also found life span extension (Liang et al. 2010; Caldeira da Silva et al. 2008; Cai et al. 2007; Stoll et al. 1997; Yen and Knoll 1992; Cotzias et al. 1977). These were deprenyl fed to Syrian hamsters (Stoll et al. 1997); deprenyl and Dinh lang root extract fed to mice (Yen and Knoll 1992); dinitrophenol fed to normal mice of a short-lived strain (Caldeira da Silva et al. 2008); L-dopa fed to male mice (Cotzias et al. 1977); marine collagen peptides fed to SpragueDawley rats (Liang et al. 2010); and reduced advanced glycation end product-containing standard mouse diet fed to mice (Cai et al. 2007). These are the only studies in the literature showing an increase in rodent longevity for which the potential effects of "voluntary" CR on life span can be confidently excluded. Four studies which controlled or measured caloric intake found no change in life span with various treatments (Smith et al. 2010; Spindler and Mote 2007; Lee et al. 2004; Pugh et al. 1999b).

Six other studies found life span extension and reported the effects of the treatments on body weight as a surrogate measure of food consumption (Table 1 and ESM Table 1). However, there are demonstrated instances in which a discordance was found between body weight and food consumption, making body weight a potentially unreliable surrogate measure of caloric consumption (see below). These treatments are: coenzyme Q10 administered orally to male Wistar rats fed a diet high in polyunsaturated fatty acids (Quiles et al. 2004); Ginkgo biloba extract 
Table 1 Summary appraisal of the published life span studies using healthy rodents

106 separate life span studies where compounds were administered to normal ${ }^{\mathrm{a}}$ rodents (less 20 contradictory melatonin studies) $^{\mathrm{b}}$

6 studies found life span extension and showed food consumption was not responsible by measuring it

Deprenyl administered orally to female hamsters

Deprenyl and Dinh lang root extract administered to mice

Dinitrophenol administered to a short-lived, normal mouse strain

L-dopa administered orally to male mice

Marine collagen peptides extended the mean life span of Sprague-Dawley rats

Reduced advanced glycation end products present in standard rodent diet

6 studies found life span extension and reported no change in weight, with data shown or details given (this list excludes studies which showed no change in food consumption listed above)

Coenzyme Q10 administered orally to male Wistar rats a diet high in polyunsaturated fatty acids

Ginkgo biloba administered orally to F344 rats

Green tea polyphenols administered orally to mice

2-Mercaptoethanol administered orally to mice

PBN administered orally to mice

Piperoxane administered by injection to rats

20 studies report LS extension but potential CR effects cannot be excluded

Body weight and/or food consumption called "unchanged", but no data given or data given but not analyzed statistically (e.g., it remains unclear whether the data are anecdotal or systematic, when and how many times during the study measurements were taken, the means and standard deviations of the measurements, and what statistical methods were used to analyze the data?)

29 studies report results that are likely due to induced "voluntary" CR

Body weights or food consumption were less than those of controls or neither was reported

36 studies report no effect on life span

3 studies report reduced LS

9 studies would be difficult to repeat or have methodological or reporting confounds that render their data of uncertain significance

Only English language publications were reviewed

${ }^{\mathrm{b}}$ Normal in this context means the animals had no known genetic defect leading to an artificially decreased life span and were not given a physical or chemical treatment to stress the animals and shorten their life span

${ }^{\mathrm{b}}$ If a publication reports the testing of a compound or compounds using more than one group of animals, each test was listed and counted separately. If a compound was tested in more than one publication, these studies are counted separately. If a compound had differential effects on the lifespan of mice of different strains in a single report, these effects were counted under multiple categories.

administered orally to male F344 rats (Winter 1998); green tea polyphenols administered in drinking water to male C57BL/6 (B6) mice (Kitani et al. 2007); 2mercaptoethanol administered orally in food to male BC3F1 mice (Heidrick et al. 1984); PBN fed to B6 male mice (Saito et al. 1998); and piperoxane administered by injection to F344 rats (Compton et al. 1995).

Twenty studies found extended life span, but potential CR effects cannot be excluded based on the data available (Table 1 and ESM Table 1). Many of these reports include statements to the effect that no change in body weight (most common) or food intake (rarely) occurred, but no data or analysis are shown. No indication is given of whether the data were anecdotal or systematic, when and how many times during the study the measurements were taken, or what statistical methods were used to analyze the data. These uncertainties, coupled with the potential fallibility of weight as a biomarker for food consumption (see below), make these studies less persuasive.

Twenty-nine other studies report life span extension by treatments, but the body weight and/or food consumption data presented in the publication suggest that induced voluntary CR was responsible for the longevity effects observed. Of the remaining studies, nine would be difficult to repeat because the composition, preparation, or mode of delivery of the 
treatment agents are published in difficult to obtain journals or are not reported.

\section{Food consumption should be measured}

Body weight is often used in longevity studies as a surrogate measure of caloric consumption (Table 1 and ESM Table 1). The vast majority of the studies using body weight as a surrogate do not report the methods used or the results obtained (ESM Table 1). Thus, the reader cannot know whether the conclusions drawn used systematic or anecdotal measures. The number of animals weighed, the number of times they were weighed, and the statistics used are not reported. Such problems are evident in two reports from the NIA Interventions Testing Program (NIHITP; Harrison et al. 2009; Strong et al. 2008; Miller et al. 2007). While the studies are unusually robust in many aspects of experimental design, including large cohorts of genetically heterogeneous mice of both sexes tested at multiple sites, most of their reports give no details regarding body weight measurements (Harrison et al. 2009; Strong et al. 2008; Miller et al. 2007). Thus, NIH-ITP investigators have reported that the same concentration of rapamycin fed to HET3 mice produced either no effect on body weight (methods and data unspecified; Harrison et al. 2009) or a $6 \%$ or $10 \%$ decrease in body weight (for females and males, respectively; Miller et al. 2011). Thus, it is possible that the mice in the first study experienced an undetected reduction in body weight. It also is unclear whether the reductions in body weight found in the second study were due to reduced caloric intake. Thus, "voluntary CR" may have played a role in the longevity effects observed. While one may seek further information from these investigators at this time, our publications are likely to outlive us.

Body weight is an unreliable surrogate measure of caloric intake. Both dietary L-dopa and dietary dinitrophenol reduce body weight without changing food consumption (Caldeira da Silva et al. 2008; Cotzias et al. 1977). A drug-induced discordance between body weight and food intake may not be uncommon. We found five agents or combination of agents that significantly decreased body weight and four agents or combination of agents which significantly increased the body weight of mice fed isocalorically (unpublished results). For example, mice fed food supplemented with four doses of nordihydroguaiaretic acid (NDGA) experienced an approximately dose-responsive decrease in body weight without a corresponding decrease in food consumption (Fig. 1). Food was packed in 1-g pellets and fed daily. Food intake for each of these groups was carefully monitored and recorded. Any uneaten food, even when masticated and dropped into the bedding, was readily identifiable by shape, color, and texture. Quantitatively, the group fed the highest dose of NDGA weighed the same or less than a $20 \%$ calorierestricted $(20 \% \mathrm{CR})$ group at most times during the study (Fig. 1). Others have reported, without showing data, that mice consuming NDGA-supplemented diets ad libitum have no change in body weight relative to controls (Strong et al. 2008). Thus, it is possible that the mice in this published study maintained their body weight by increasing food consumption. Feeding measured quantities of food and monitoring of its consumption ensures that life span data are not confounded by changes in caloric consumption. This reduces the likelihood of CR-related changes in life span (Merry 2002; Compton et al. 1995).

Monitoring of both food consumption and body weight will identify instances in which a compound produces a discordance between them. Drug-induced changes in activity, metabolic rate, or intestinal absorption of calories might lead to such a discordance, which would not be detected by monitoring of only body weight. Once detected, a discordance can be investigated further using measurements of spontaneous activity, metabolic rate, and absorption of calories (e.g., Westbrook et al. 2009; Adams et al. 2006). Thus, measured feeding coupled with body weight monitoring is a much more robust approach to life span studies than body weight monitoring alone.

\section{Methods for isocaloric feeding}

In the author's experience, measuring food consumption is less difficult and expensive than it is sometimes assumed to be. In an ongoing longevity study involving 2,400 mice, measured feeding is $\sim 9 \%$ of total costs. To deliver a known amount of food to each cage conveniently, we use the method described by Weindruch and colleagues (Pugh et al. 1999a). The food (AIN-93M) and any additional components are cold-packed into 1-g pellets by Bio- 


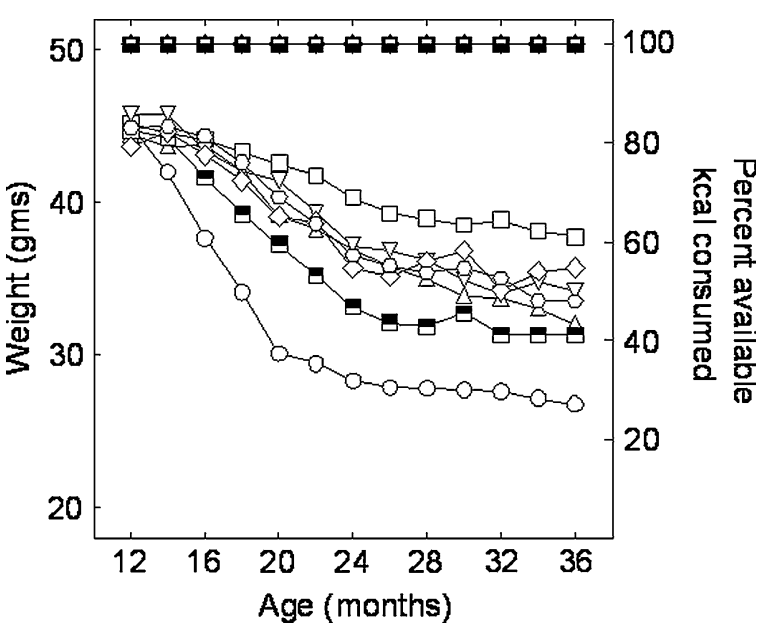

Serv (Frenchtown, NJ). These round pellets are conveniently scooped into a $1.6-\mathrm{cm}$ inner diameter Plexiglas tube fitted with a commercially available plastic cap. Tubes cut to different lengths are used to deliver different numbers of pellets to the cages.

If a supplemented diet is under-consumed, flavoring can be added, the supplement can be changed to an agent with similar actions, the supplement concentration in the food can be reduced, or, if desired, the amount of food given to a control group can be decreased to that of the test agent. We slightly underfeed all the mice in our studies to insure that all food is eaten.

\section{Healthy, long-lived rodents, such as an F1 hybrid or a more genetically heterogeneous mouse should be used for compound screening}

During our survey of the literature, we found many reports of life span-based compound screening performed with short-lived or enfeebled rodents (data not shown). By "enfeebled," we mean natural or selected rodent lines that have genetic (or possibly epigenetic) changes that reduce longevity and health relative to their unaltered parental or control strains. For example, many studies utilized senescence-accelerated prone mouse strains (SAMP1 through SAMP9) to rapidly screen for longevity therapeutics (Rodriguez et al. 2008; Li et al. 2007; Umezawa et al. 2000; Boldyrev et al. 1999; Kumari et al. 1997; Edamatsu et al. 1995; Zhang et al. 1994). SAMP mice suffer from the early onset of a spectrum of age-related pathologies which abbreviate their life span. We found only one study in which the effectiveness of an agent was
Fig. 1 Isocaloric feeding of diets containing NDGA reduced body weight without altering food consumption. The left axis shows the mean bimonthly weights of dietary groups fed AIN93M diet with no additional additives (empty square) or AIN$93 \mathrm{M}$ diet containing NDGA at $1.5 \mathrm{-g} / \mathrm{kg}$ diet (empty triangle), $2.5 \mathrm{~g} / \mathrm{kg}$ diet (empty diamond), 3.5-g/kg diet (empty hexagon), and $4.5-\mathrm{g} / \mathrm{kg}$ diet $(\mathbf{\square})$; a $20 \% \mathrm{CR}$ diet (empty downturned triangle); or a $40 \% \mathrm{CR}$ diet (circle). The mice were shifted from chow feeding to the defined diets at 12 months of age. The right axis shows the percentage of the kilocalories fed to each group of mice which were actually consumed for the group fed AIN-93M diet with no additives (filled square); AIN$93 \mathrm{M}$ diet containing NDGA at $1.5 \mathrm{-g} / \mathrm{kg}$ diet (filled triangle), $2.5 \mathrm{-g} / \mathrm{kg}$ diet (filled diamond), $3.5 \mathrm{-g} / \mathrm{kg}$ diet (filled hexagon), and $4.5-\mathrm{g} / \mathrm{kg}$ diet (口); a $20 \%$ CR diet (filled downturned triangle); or a $40 \% \mathrm{CR}$ diet (filled circle). The symbols representing food consumption are superimposed in the figure, making them difficult to distinguish because the mice ate essentially all their food. Error bars and symbols for statistical significance were omitted for the sake of clarity. The body weights were significantly different than controls, as judged by the non-parametric Mann-Whitney test, for the NDGA $1.5-\mathrm{g} / \mathrm{kg}$ diet group at 22 months $(P<0.01), 24$ months $(P<0.001)$, 26 months $(P<0.01), 28$ months $(P<0.05)$, and 30 months $(P<$ $0.01)$; for the $2.5-\mathrm{mg} / \mathrm{kg}$ diet group at 18 months $(P<0.01), 20$ 26 months $(P<0.001)$, and 28 months $(P<0.01)$; for the 3.5$\mathrm{mg} / \mathrm{kg}$ diet group at 20 and 22 months $(P<0.01), 24$ and 26 months $(P<0.001)$, and 28 and 30 months $(P<0.01)$; and for the $4.5-\mathrm{mg} / \mathrm{kg}$ diet group at 16 months $(P<0.01)$ and 18 30 months $(P<0.001)$. The mice were shifted from chow feeding to the defined diets at 12 months of age. These studies used male B6C3F1 mice (Harlan Breeders, Indianapolis) randomly assigned to treatment groups at 3 weeks of age. At 12 months of age, the mice were shifted from ad libitum chow feeding (Diet no. 5001, Purina Mills, Richmond, IN) to daily feeding with either $13.3 \mathrm{kcal} /$ day per mouse of control diet (AIN-93M, Diet no. F05312; Bioserv, Frenchtown, NJ) or daily feeding with an identical quantity of control diet supplemented with the indicated concentrations of NDGA. The $20 \%$ CR group was shifted from ad libitum chow feeding to $11 \mathrm{kcal} /$ day per mouse of AIN-93M 20\% Restricted Diet (Diet no. F06298, Bioserv). The $40 \%$ CR group was shifted from ad libitum chow feeding to $11 \mathrm{kcal} /$ day per mouse of AIN-93M 20\% Restricted Diet for 2 weeks and thereafter to $7.46 \mathrm{kcal} /$ day of AIN-93M 40\% Restricted Diet (Diet no. F05314, Bioserv). The diets for the $20 \%$ and $40 \%$ calorically restricted groups were fortified so the mice received fewer calories in the form of carbohydrate than the other groups, but approximately equal amounts of fat, protein, vitamins, and minerals. All mice were fed the amounts indicated daily. Food consumption was monitored at the time of feeding, and any food left was noted and removed. With rare exceptions, all food was eaten each day. The drugs were mixed with powered diet and cold-pressed into 1-g pellets by Bio-serv. The food was stored moisture free at $4{ }^{\circ} \mathrm{C}$ until used. The mice drank acidified $(\mathrm{pH}$ 4.0) tap water ad libitum and were maintained on a 12 -h light/dark cycle at $22^{\circ} \mathrm{C}$. Cohorts of 296 negative control mice and $36 \mathrm{CR}$ and treated mice were utilized

tested in both an SAMP mouse (SAMP8) and in one of its associated control mouse strains (SAMPR1; 
Zhang et al. 1994). In this study, a botanical which extend the life span of SAMP8 mice did not extend the life span of the control strain. Similarly, resveratrol was reported to extend the life span of high fat-fed, obese, and diabetic mice (Baur et al. 2006). While this article has been cited by many as evidence that resveratrol can extend mammalian life span, the results did not translate to healthy mice (Pearson et al. 2008). Thus, screening agents in enfeebled rodents has not yet been shown to facilitate the identification of compounds which extend the life span of healthy animals.

For these reasons, studies designed to identify longevity therapeutics should utilize long-lived mice, such as an F1 hybrid or more genetically heterogeneous mouse. F1 hybrid mice, which are widely available, are genetically heterozygous at all loci for which their parents are heteroallelic. They are more disease- and stress-resistant and have larger litters and longer life spans than their inbred parental lines (Flurkey et al. 2009). HET3 mice, which are produced using a four-way crossbreeding scheme, are more genetically heterogeneous than F1 mice and are used by the NIH-ITP. However, they are more difficult to produce and have shorter life spans than some F1 mice. For example, B6C3F1 mice have a mean life span of about 915 days (Spindler and Mote 2007; Pugh et al. 1999b; Smith and Walford 1977), while HET3 mice have a mean life span of about 800 days (Strong et al. 2008). Longer life spans are usually regarded as signs of greater vigor. Outbred mice, which are even more genetically heterogeneous than HET3 mice, are more vigorous and less expensive than inbred mice (Flurkey et al. 2009). However, they have the disadvantage of being genetically undefined. Because each mouse is genetically unique, study results can be more varied and thus more difficult to reproduce.

\section{Chemically defined diets should be used for gerontological research}

There are three general categories of rodent diets: cereal-based (non-purified), purified, and chemically defined (Kozul et al. 2008; Reeves et al. 1993; American Institute of Nutrition ad hoc Committee on Standards for Nutritional Studies 1977). The majority of the studies summarized in ESM Table 1 appeared to have used non-purified or purified cereal-based diets. However, cereal-based diets are often variable in composition (American Institute of Nutrition ad hoc Committee on Standards for Nutritional Studies 1977), and this variability, and the presence of trace contaminants, can strongly influence experimental results (Kozul et al. 2008; Jensen and Ritskes-Hoitinga 2007; Allred et al. 2004; Thigpen et al. 2004, 2003). For example, Prolab-RMH 1000 rodent chow contains appreciable quantities of polychlorinated dibenzo- $p$-dioxins and dibenzofurans, probably from pesticide residues (Schecter et al. 1996). Purina Laboratory Rodent diet 5001 (LRD-5001) contains high concentrations of methylmercury and a mixture of inorganic and organic arsenic compounds at a concentration 36 times the EPA-recommended level for drinking water (Kozul et al. 2008; Weiss et al. 2005). The specifications for diets such as NIH-31 allow manufacturers to use any of a number of sources of protein, including fish meal, a possible source of arsenic and other contaminants, or soy, a possible source of pesticide residue. Thus, purified, defined diets are preferable.

\section{Use of a positive control is highly desirable}

Many life span studies are published without the benefit of a positive control group, such as a $40 \% \mathrm{CR}$ group. If none of the compounds tested in a study extend life span, the possibility cannot be excluded that the rodents would not respond to a longevity treatment under the study conditions. Few reviewers would endorse the publication of negative biochemical data without the inclusion of a positive control to show that the assay was working. This should be similarly important for rodent life span studies.

\section{Dosages of agents tested in rodents}

The dosages at which potential therapeutics are tested in rodents must balance a number of competing theoretical and practical issues. Ideally, one would like to know that a therapeutic level of the agent is maintained throughout a life span study. Of course, the ideal therapeutic level of an agent is not known for most life span studies. Furthermore, food intake, body volume, intestinal absorption, and metabolism 
may change with age. Monitoring the blood levels of an agent throughout a life span study would be difficult and expensive. Group sizes which would make rodents available for testing throughout the study are often impractical.

Several approaches can mitigate these limitations. Published studies with well-defined treatment endpoints can be used to estimate dosages. In this way, one can be reasonably certain that a therapeutic level of the agent is achieved. Initial signs that a dosage is too high, such as reduced food intake or inattention to grooming, can be used to adjust dosages "on the fly." Where rodent studies cannot be found, equivalent rodent dosages can be calculated from human dosages using default crossspecies scaling factors (Reagan-Shaw et al. 2008; US EPA 2005; Rhomberg and Lewandowski 2004; Dourson et al. 1992, 1996; Dourson and Stara 1983). These scaling factors are often used to set and access drug dosages in human and animal studies (e.g., Chalastanis et al. 2010). Empirically, small animals have been found to require larger dosages per gram body weight than larger animals. These differences are due to pharmacokinetic differences (e.g., rates of uptake, metabolism, and clearance of compounds) and to pharmacodynamic differences (e.g., rates of damage to macromolecules, cellular repair and regeneration, signaling cascades, and proliferative responses) between small and large animals. One widely used scaling formula increases the human dosage in milligrams per kilogram body weight/day by tenfold to obtain the equivalent mouse dosage. Another scaling factor also in use is based on the $3 / 4$ power of body weight [i.e., (milligrams/kilogram body weight) (3/4 $^{3 / 4}$ day], which leads to equivalent mouse dosages that are about sevenfold higher than the equivalent human dosages. While these calculations were initially developed for chemotherapeutics, they are also used as starting points when human dosages must be extrapolated from preclinical rodent data (Chalastanis et al. 2010).

\section{Summary: the preferred design for testing potential longevity therapeutics using mouse life span studies}

Based on the information reviewed above, we recommend a number of design parameters essential or highly desirable for rodent life span assays: (1) The diets should be fed in measured amounts and consumption monitored. Body weight should be monitored regularly. These measurements and their statistical analysis should be reported. (2) A longlived, healthy rodent strain should be used, preferably an F1 or further outcrossed strain. (3) Chemically defined diets should be used. They ensure the greatest degree of reproducibility and avoid the confounds introduced by contaminants or compositional variability. (4) Use of a positive control is highly desirable. Without a positive control, negative results are of questionable significance. We use a $40 \%$ CR control, which also allows us to calibrate the effects of a treatment (e.g., Fig. 1). (5) Dosages can be chosen using treatment endpoints gleaned from the literature or, where necessary, from human dosages using accepted cross-species scaling factors. Use of these methods will produce a more reliable literature on which to base further studies.

Acknowledgments The author would like to thank Mehgan Hassanzadah and Patricia Mote for their help in the preparation of this manuscript.

Open Access This article is distributed under the terms of the Creative Commons Attribution Noncommercial License which permits any noncommercial use, distribution, and reproduction in any medium, provided the original author(s) and source are credited.

\section{References}

Adams SH, Lei C, Jodka CM, Nikoulina SE, Hoyt JA, Gedulin B, Mack CM, Kendall ES (2006) PYY[3-36] administration decreases the respiratory quotient and reduces adiposity in diet-induced obese mice. J Nutr 136:195-201

Allred CD, Allred KF, Ju YH, Clausen LM, Doerge DR, Schantz SL, Korol DL, Wallig MA, Helferich WG (2004) Dietary genistein results in larger MNU-induced, estrogen-dependent mammary tumors following ovariectomy of Sprague-Dawley rats. Carcinogenesis 25:211218

American of Nutrition ad hoc Committee on Standards for Nutritional Studies (1977) Report of the American Institute of Nutrition ad hoc Committee on Standards for Nutritional Studies. J Nutr 107:1340-1348

Anisimov VN (1982) Carcinogenesis and aging. III. The role of age in initiation and promotion of carcinogenesis. Exp Pathol 22:131-147

Anisimov VN, Popovich IG, Zabezhinski MA, Anisimov SV, Vesnushkin GM, Vinogradova IA (2006) Melatonin as antioxidant, geroprotector and anticarcinogen. Biochim Biophys Acta 1757:573-589 
Barger JL, Kayo T, Pugh TD, Prolla TA, Weindruch R (2008) Short-term consumption of a resveratrol-containing nutraceutical mixture mimics gene expression of long-term caloric restriction in mouse heart. Exp Gerontol 43:859-866

Baur JA, Pearson KJ, Price NL, Jamieson HA, Lerin C, Kalra A, Prabhu VV, Allard JS, Lopez-Lluch G, Lewis K, Pistell PJ, Poosala S, Becker KG, Boss O, Gwinn D, Wang M, Ramaswamy S, Fishbein KW, Spencer RG, Lakatta EG, Le Couteur D, Shaw RJ, Navas P, Puigserver P, Ingram DK, de Cabo R, Sinclair DA (2006) Resveratrol improves health and survival of mice on a high-calorie diet. Nature 444:337-342

Boldyrev AA, Gallant SC, Sukhich GT (1999) Carnosine, the protective, anti-aging peptide. Biosci Rep 19:581587

Brown-Borg HM, Borg KE, Meliska CJ, Bartke A (1996) Dwarf mice and the ageing process. Nature 384:33

Cai W, He JC, Zhu L, Chen X, Wallenstein S, Striker GE, Vlassara H (2007) Reduced oxidant stress and extended lifespan in mice exposed to a low glycotoxin diet: association with increased AGER1 expression. Am J Pathol 170:1893-1902

Caldeira da Silva CC, Cerqueira FM, Barbosa LF, Medeiros MH, Kowaltowski AJ (2008) Mild mitochondrial uncoupling in mice affects energy metabolism, redox balance and longevity. Aging Cell 7:552-560

Cao SX, Dhahbi JM, Mote PL, Spindler SR (2001) Genomic profiling of short- and long-term caloric restriction effects in the liver of aging mice. Proc Natl Acad Sci USA 98:10630-10635

Chalastanis A, Penard-Lacronique V, Svrcek M, Defaweux V, Antoine N, Buhard O, Dumont S, Fabiani B, Renault I, Tubacher E, Flejou JF, Te RH, Duval A, Muleris M (2010) Azathioprine-induced carcinogenesis in mice according to Msh2 genotype. J Natl Cancer Inst 102:1731-1740

Compton DM, Dietrich KL, Smith JS (1995) Influence of the alpha 2 noradrenergic antagonist piperoxane on longevity in the Fischer-344 rat: a preliminary report. Psychol Rep 77:139-142

Corton JC, Apte U, Anderson SP, Limaye P, Yoon L, Latendresse J, Dunn C, Everitt JI, Voss KA, Swanson C, Kimbrough C, Wong JS, Gill SS, Chandraratna RA, Kwak MK, Kensler TW, Stulnig TM, Steffensen KR, Gustafsson JA, Mehendale HM (2004) Mimetics of caloric restriction include agonists of lipid-activated nuclear receptors. J Biol Chem 279:46204-46212

Coschigano KT, Clemmons D, Bellush LL, Kopchick JJ (2000) Assessment of growth parameters and life span of GHR/BP gene-disrupted mice. Endocrinology 141:2608-2613

Cotzias GC, Miller ST, Tang LC, Papavasiliou PS (1977) Levodopa, fertility, and longevity. Science 196:549-551

Dhahbi JM, Mote PL, Fahy GM, Spindler SR (2005) Identification of potential caloric restriction mimetics by microarray profiling. Physiol Genomics 23:343-350

Dourson ML, Stara JF (1983) Regulatory history and experimental support of uncertainty (safety) factors. Regul Toxicol Pharmacol 3:224-238

Dourson ML, Knauf LA, Swartout JC (1992) On reference dose (RfD) and its underlying toxicity data base. Toxicol Ind Health 8:171-189
Dourson ML, Felter SP, Robinson D (1996) Evolution of science-based uncertainty factors in noncancer risk assessment. Regul Toxicol Pharmacol 24:108-120

Edamatsu R, Mori A, Packer L (1995) The spin-trap N-tertalpha-phenyl-butylnitrone prolongs the life span of the senescence accelerated mouse. Biochem Biophys Res Commun 211:847-849

Ferder L, Inserra F, Romano L, Ercole L, Pszenny V (1993) Effects of angiotensin-converting enzyme inhibition on mitochondrial number in the aging mouse. Am J Physiol 265:C15-C18

Flurkey K, Papaconstantinou J, Miller RA, Harrison DE (2001) Lifespan extension and delayed immune and collagen aging in mutant mice with defects in growth hormone production. Proc Natl Acad Sci USA 98:6736-6741

Flurkey K, Currer JM, Leiter EH, Witham B (2009) The Jackson Laboratory handbook on genetically standardized mice. The Jackson Laboratory

Harrison DE, Strong R, Sharp ZD, Nelson JF, Astle CM, Flurkey K, Nadon NL, Wilkinson JE, Frenkel K, Carter CS, Pahor M, Javors MA, Fernandez E, Miller RA (2009) Rapamycin fed late in life extends lifespan in genetically heterogeneous mice. Nature 460:392-395

Heidrick ML, Hendricks LC, Cook DE (1984) Effect of dietary 2-mercaptoethanol on the life span, immune system, tumor incidence and lipid peroxidation damage in spleen lymphocytes of aging BC3F1 mice. Mech Ageing Dev 27:341-358

Holzenberger M, Dupont J, Ducos B, Leneuve P, Geloen A, Even PC, Cervera P, Le Bouc Y (2003) IGF-1 receptor regulates lifespan and resistance to oxidative stress in mice. Nature 421:182-187

Jensen MN, Ritskes-Hoitinga M (2007) How isoflavone levels in common rodent diets can interfere with the value of animal models and with experimental results. Lab Anim $41: 1-18$

Kitani K, Osawa T, Yokozawa T (2007) The effects of tetrahydrocurcumin and green tea polyphenol on the survival of male C57BL/6 mice. Biogerontology 8:567-573

Kozul CD, Nomikos AP, Hampton TH, Warnke LA, Gosse JA, Davey JC, Thorpe JE, Jackson BP, Ihnat MA, Hamilton JW (2008) Laboratory diet profoundly alters gene expression and confounds genomic analysis in mouse liver and lung. Chem Biol Interact 173:129-140

Kumari MV, Yoneda T, Hiramatsu M (1997) Effect of "beta CATECHIN" on the life span of senescence accelerated mice (SAM-P8 strain). Biochem Mol Biol Int 41:10051011

Kurosu H, Yamamoto M, Clark JD, Pastor JV, Nandi A, Gurnani P, McGuinness OP, Chikuda H, Yamaguchi M, Kawaguchi H, Shimomura I, Takayama Y, Herz J, Kahn CR, Rosenblatt KP, Kuro-o M (2005) Suppression of aging in mice by the hormone Klotho. Science 309:18291833

LaBella F, Vivian S (1978) Beta-aminopropiontrile promotes longevity in mice. Exp Gerontol 13:251-254

Lee CK, Pugh TD, Klopp RG, Edwards J, Allison DB, Weindruch R, Prolla TA (2004) The impact of alphalipoic acid, coenzyme Q10 and caloric restriction on life span and gene expression patterns in mice. Free Radic Biol Med 36:1043-1057 
Li L, Ng TB, Song M, Yuan F, Liu ZK, Wang CL, Jiang Y, Fu M, Liu F (2007) A polysaccharide-peptide complex from abalone mushroom (Pleurotus abalonus) fruiting bodies increases activities and gene expression of antioxidant enzymes and reduces lipid peroxidation in senescence-accelerated mice. Appl Microbiol Biotechnol 75:863-869

Liang J, Pei XR, Wang N, Zhang ZF, Wang JB, Li Y (2010) Marine collagen peptides prepared from chum salmon (Oncorhynchus keta) skin extend the life span and inhibit spontaneous tumor incidence in Sprague-Dawley rats. J Med Food 13:757-770

Lippman RD (1981) The prolongation of life: a comparison of antioxidants and geroprotectors versus superoxide in human mitochondria. J Gerontol 36:550-557

McCay CM, Crowell MF, Maynard LA (1935) The effect of retarded growth upon the length of the life span and upon the ultimate body size. J Nutr 10:63-79

Merry BJ (2002) Molecular mechanisms linking calorie restriction and longevity. Int $\mathrm{J}$ Biochem Cell Biol 34:1340-1354

Miller RA, Harrison DE, Astle CM, Floyd RA, Flurkey K, Hensley KL, Javors MA, Leeuwenburgh C, Nelson JF, Ongini E, Nadon NL, Warner HR, Strong R (2007) An aging Interventions Testing Program: study design and interim report. Aging Cell 6:565-575

Miller RA, Harrison DE, Astle CM, Baur JA, Boyd AR, de Cabo R, Fernandez E, Flurkey K, Javors MA, Nelson JF, Orihuela CJ, Pletcher S, Sharp ZD, Sinclair D, Starnes JW, Wilkinson JE, Nadon NL, Strong R (2011) Rapamycin, but not resveratrol or simvastatin, extends life span of genetically heterogeneous mice. J Gerontol A Biol Sci Med Sci 66:191-201

Pearson KJ, Baur JA, Lewis KN, Peshkin L, Price NL, Labinskyy N, Swindell WR, Kamara D, Minor RK, Perez E, Jamieson HA, Zhang Y, Dunn SR, Sharma K, Pleshko N, Woollett LA, Csiszar A, Ikeno Y, Le Couteur D, Elliott PJ, Becker KG, Navas P, Ingram DK, Wolf NS, Ungvari Z, Sinclair DA, de Cabo R (2008) Resveratrol delays agerelated deterioration and mimics transcriptional aspects of dietary restriction without extending life span. Cell Metab 8:157-168

Pugh TD, Klopp RG, Weindruch R (1999a) Controlling caloric consumption: protocols for rodents and rhesus monkeys. Neurobiol Aging 20:157-165

Pugh TD, Oberley TD, Weindruch R (1999b) Dietary intervention at middle age: caloric restriction but not dehydroepiandrosterone sulfate increases lifespan and lifetime cancer incidence in mice. Cancer Res 59:16421648

Quiles JL, Ochoa JJ, Huertas JR, Mataix J (2004) Coenzyme Q supplementation protects from age-related DNA doublestrand breaks and increases lifespan in rats fed on a PUFArich diet. Exp Gerontol 39:189-194

Reagan-Shaw S, Nihal M, Ahmad N (2008) Dose translation from animal to human studies revisited. FASEB J 22:659661

Reeves PG, Nielsen FH, Fahey GC Jr (1993) AIN-93 purified diets for laboratory rodents: final report of the American Institute of Nutrition ad hoc Writing Committee on the reformulation of the AIN-76A rodent diet. J Nutr 123:1939-1951
Rhomberg LR, Lewandowski TA (2004) Methods for identifying a default cross-species scaling factor. U.S. Environmental Protection Agency, Washington

Rodriguez MI, Escames G, Lopez LC, Lopez A, Garcia JA, Ortiz F, Sanchez V, Romeu M, Acuna-Castroviejo D (2008) Improved mitochondrial function and increased life span after chronic melatonin treatment in senescent prone mice. Exp Gerontol 43:749-756

Roth GS, Ingram DK, Lane MA (2001) Caloric restriction in primates and relevance to humans. Ann NY Acad Sci 928:305-315

Saito K, Yoshioka H, Cutler RG (1998) A spin trap, N-tertbutyl-alpha-phenylnitrone extends the life span of mice. Biosci Biotechnol Biochem 62:792-794

Schecter AJ, Olson J, Papke O (1996) Exposure of laboratory animals to polychlorinated dibenzodioxins and polychlorinated dibenzofurans from commerical rodent chow. Chemosphere 32:501-508

Sebesteny A (1991) Necessity of a more standardized microbiological characterization of rodents for aging studies. Neurobiol Aging 12:663-668

Selman C, Lingard S, Choudhury AI, Batterham RL, Claret M, Clements M, Ramadani F, Okkenhaug K, Schuster E, Blanc E, Piper MD, Al Qassab H, Speakman JR, Carmignac D, Robinson IC, Thornton JM, Gems D, Partridge L, Withers DJ (2008) Evidence for lifespan extension and delayed age-related biomarkers in insulin receptor substrate 1 null mice. FASEB J 22:807-818

Smith GS, Walford RL (1977) Influence of the main histocompatibility complex on ageing in mice. Nature 270:727729

Smith DL Jr, Elam CF Jr, Mattison JA, Lane MA, Roth GS, Ingram DK, Allison DB (2010) Metformin supplementation and life span in Fischer-344 rats. J Gerontol A Biol Sci Med Sci 65:468-474

Sperling GA, Loosli JK, Lupien P, McCay CM (1978) Effect of sulfamerazine and exercise on life span of rats and hamsters. Gerontology 24:220-224

Spindler SR (2006) Use of microarray biomarkers to identify longevity therapeutics. Aging Cell 5:39-50

Spindler SR (2010) Caloric restriction: from soup to nuts. Ageing Res Rev 9:324-353

Spindler SR, Dhahbi JM (2007) Conserved and tissue-specific genic and physiologic responses to caloric restriction and altered IGFI signaling in mitotic and postmitotic tissues. Annu Rev Nutr 27:193-217

Spindler SR, Mote PL (2007) Screening candidate longevity therapeutics using gene-expression arrays. Gerontology 53:306-321

Stoll S, Hafner U, Kranzlin B, Muller WE (1997) Chronic treatment of Syrian hamsters with low-dose selegiline increases life span in females but not males. Neurobiol Aging 18:205-211

Strong R, Miller RA, Astle CM, Floyd RA, Flurkey K, Hensley KL, Javors MA, Leeuwenburgh C, Nelson JF, Ongini E, Nadon NL, Warner HR, Harrison DE (2008) Nordihydroguaiaretic acid and aspirin increase lifespan of genetically heterogeneous male mice. Aging Cell 7:641-650

Taguchi A, Wartschow LM, White MF (2007) Brain IRS2 signaling coordinates life span and nutrient homeostasis. Science 317:369-372 
Thigpen JE, Haseman JK, Saunders HE, Setchell KD, Grant MG, Forsythe DB (2003) Dietary phytoestrogens accelerate the time of vaginal opening in immature CD-1 mice. Comp Med 53:607-615

Thigpen JE, Setchell KD, Saunders HE, Haseman JK, Grant MG, Forsythe DB (2004) Selecting the appropriate rodent diet for endocrine disruptor research and testing studies. ILAR J 45:401-416

Umezawa M, Takeda T, Kogishi K, Higuchi K, Matushita T, Wang J, Chiba T, Hosokawa M (2000) Serum lipid concentrations and mean life span are modulated by dietary polyunsaturated fatty acids in the senescenceaccelerated mouse. J Nutr 130:221-227

US EPA (2005) Guidance for industry estimating the maximum safe starting dose in initial clinical trials for therapeutics in adult healthy volunteers. Office of New Drugs in the Center for Drug Evaluation and Research (CDER) at the Food and Drug Administration. Food and Drug Administration, Rockville, MD

Weindruch R, Keenan KP, Carney JM, Fernandes G, Feuers RJ, Floyd RA, Halter JB, Ramsey JJ, Richardson A, Roth GS, Spindler SR (2001) Caloric restriction mimetics: metabolic interventions. J Gerontol Biol Sci 56:20-33
Weiss B, Stern S, Cernichiari E, Gelein R (2005) Methylmercury contamination of laboratory animal diets. Environ Health Perspect 113:1120-1122

Westbrook R, Bonkowski MS, Strader AD, Bartke A (2009) Alterations in oxygen consumption, respiratory quotient, and heat production in long-lived GHRKO and Ames dwarf mice, and short-lived bGH transgenic mice. J Gerontol A Biol Sci Med Sci 64:443-451

Winter JC (1998) The effects of an extract of Ginkgo biloba, $\mathrm{EGb} 761$, on cognitive behavior and longevity in the rat. Physiol Behav 63:425-433

Yen TT, Knoll J (1992) Extension of lifespan in mice treated with Dinh lang (Policias fruticosum L.) and (-)deprenyl. Acta Physiol Hung 79:119-124

Zhang Y, Takashina K, Saito H, Nishiyama N (1994) Antiaging effect of DX-9386 in senescence accelerated mouse. Biol Pharm Bull 17:866-868

Zhou Y, Xu BC, Maheshwari HG, He L, Reed M, Lozykowski M, Okada S, Cataldo L, Coschigamo K, Wagner TE, Baumann G, Kopchick JJ (1997) A mammalian model for Laron syndrome produced by targeted disruption of the mouse growth hormone receptor/binding protein gene (the Laron mouse). Proc Natl Acad Sci USA 94:13215-13220 